How can emerging powers speak?

On theorists, native informants and quasi-officials in International Relations discourse Kristensen, Peter Marcus

Published in:

Third World Quarterly

DOI:

10.1080/01436597.2015.1023288

Publication date:

2015

Citation for published version (APA):

Kristensen, P. M. (2015). How can emerging powers speak? On theorists, native informants and quasi-officials in International Relations discourse. Third World Quarterly, 36(4), 637-653. [1].

https://doi.org/10.1080/01436597.2015.1023288 


\title{
How Can Emerging Powers Speak? On Theorists, Native Informants and Quasi-Officials in International Relations Discourse
}

\author{
Peter Marcus Kristensen \\ University of Copenhagen
}

\begin{abstract}
Emerging powers like China, India and Brazil receive growing attention as objects in International Relations (IR) discourse. Scholars from these emerging powers are rarely present as subjects in mainstream IR discourse, however. This paper interrogates the conditions for scholars in emerging powers to speak back to the mainstream discipline. It argues, firstly, that 'theory speak' is rare from scholars based in periphery countries perceived to be 'emerging powers'. Despite increasing efforts to create a 'homegrown' theoretical discourse in China, India and Brazil, few articles in mainstream journals present novel theoretical frameworks and particularly not framed as non-Western/Southern theory or even as a 'Chinese school' or 'Brazilian concepts'. Secondly, scholars from emerging powers tend to speak as 'native informants' about their own country, not about general aspects of 'the international'. Thirdly, some scholars even speak as 'quasi-officials', that is, they speak for their country.
\end{abstract}

Keywords: Emerging Powers, BRICS, IR discourse, Journals, Theory, Native Informants

\section{Emerging Powers in a Hegemonic Discipline}

Emerging powers like China, India and Brazil receive growing attention as objects in International Relations (IR) discourse. ${ }^{1}$ The proportion of IR articles with China in their topic in all IR journals in the Web of Science is now almost 8\%, up from $4-5 \%$ in the 1990 s and $2-3 \%$ in the 1980 s. Articles on India and Brazil are still less than $2 \%$ but growing. Scholars from these emerging powers are rarely present as subjects in mainstream IR discourse, however. Only 512 of the 6914 articles with China in their topic have a Chinese author. Only 137 of the 1940 articles with India in their topic have an Indian author, and 149 of the 951 articles on Brazil have a Brazilian author. There has been growing resistance against this objectification in 'emerging powers' like China, India and Brazil. This has led some scholars in these countries to theorize from 'non-Western' or 'Southern' perspectives on IR, especially to recover ancient traditions, philosophies and historical practices. To speak back to Western IR on emerging powers rather than only be spoken for. The trend is notable in China where IR scholars debate how to construct a "Chinese School" of IR entered on the puzzle of the "Peaceful Rise of China" and building upon ancient Chinese culture, history and philosophy. ${ }^{2}$ Indian IR scholars have also lamented India's reliance on Western theoretical frameworks and called instead for constructing "indigenous theories" now that India is emerging as a major power. ${ }^{3}$ Some Brazilian scholars have promoted the development of "Brazilian concepts" to counter US theories. ${ }^{4}$ As this paper demonstrates, however, these theoretical and conceptual debates have gone largely unnoticed in mainstream IR discourse. 
One reason is simply that IR as a discipline operates through a core-periphery logic: a division of labor where the main protagonists are scholars in the Anglo-American core that produce the advanced theoretical goods of IR which are then disseminated uni-directionally to scholars in a penetrated periphery. Periphery scholars do not speak back to the core, except perhaps in the sense of providing some raw empirical materials. ${ }^{5}$ However, few studies have actually studied the position of emerging powers in these import-export patterns of IR. Some country-specific studies have looked at the 'import' of Euro-American theories in emerging powers but little has been said about the 'export' of IR to the Anglo-American mainstream discipline. This paper interrogates whether scholars in the three 'non-core' emerging powers China, India and Brazil have been successful in entering Anglo-American mainstream theoretical journals, and, if so, how can they speak in mainstream IR?

\section{Chinese, Indian and Brazilian Scholarship in Mainstream IR Journals}

There are a number of methodological considerations when examining how emerging powers can speak in IR discourse. The purpose is not to map the 'non-Western' IR theory debates outlined above. This would require an engagement with scholarship produced outside the core of the discipline rather than that accepted by the mainstream discipline. My reading of Chinese, Indian and Brazilian scholarship published in mainstream Anglophone journals tells us more about the hegemonic structures of mainstream IR than it does about IR in China, India and Brazil per se. One reason is that so little scholarship from China, India and Brazil makes it into these journals. ${ }^{6}$ In all the 100,510 articles published in IR journals in Web of Science from 1990 to 2014 (October 20), China accounts only for $0.91 \%$ of all articles (915 articles), India for $0.29 \%$ (292 articles), and Brazil for $0.27 \%$ of all articles (271 articles). This ranks them $13^{\text {th }}, 31^{\text {st }}$ and $32^{\text {nd }}$, respectively, after the smaller IR communities of Belgium or Switzerland. The paper argues that these restraints make it all the more interesting to study what kinds of scholarship produced by scholars based outside the West does gets published in mainstream journals. This exercise illustrates what the mainstream discipline can accept as 'being IR' when coming from authors based in China, India and Brazil.

Another important caveat is whether we should even expect Chinese, Indian and Brazilian scholarship in Western mainstream journals. It is important to emphasize that social structures and material incentives in the IR disciplines in China, India and Brazil do not necessarily favor participation in the mainstream 'Western' discipline compared to, say, national or regional journals or perhaps non-journal formats like monographs. There is an extensive and growing national journal market in China and most Chinese IR scholars prefer to publish in these journals although 'international' publications are increasingly incentivized. ${ }^{7}$ An alternative strategy has also been to 'internationalize' local journals by publishing them in English. The establishment of Chinese Journal of International Politics (CJIP) that focuses on China's rise, Chinese ideas and theory can be interpreted as a way to spearhead Chinese IR into Anglophone IR discourse. ${ }^{8}$ The Brazilian publication space is arguably more limited and marked by discontinuity. ${ }^{9}$ National journals like Revista Brasileira de Politica Internacional, Contexto Internacional, Politica Externa and Cena Internacional are usually considered the main IR journals but elaborate bibliometric management schemes have been implemented to incentivize 'international' Web of Science publications. As a result the Revista Brasileira de Politica Internacional was recently listed in the Web of Science (as the only Brazilian IR journal) and also accepts publications in English. The growing orientation towards mainstream Anglophone IR is also evident in the establishment of Brazilian journals that publish (some) articles in English, e.g. Austral: The Brazilian Journal of Strategy and International Relations and Brazilian Journal of International Relations. India has long had a number of Anglophone IR journals-International Studies is the most prominent but also South Asian Survey, 
Strategic Analysis and numerous area studies journals - that may have started as local, even inhouse, journals but later became outlets for quality articles by both Indian and foreign authors. ${ }^{10}$ The relatively long history of English-language publications accessible by scholars abroad, Bajpai argued, should give easier access to Anglo-American discourse than in most other countries. ${ }^{11}$ Nevertheless, there is a widespread disappointment that Indian IR has not entered "international" journals. ${ }^{12}$ Journals published abroad are seen as "difficult to penetrate" and thus Indian scholars tend to publish books. ${ }^{13}$ In sum, IR in China, India and Brazil may be primarily oriented towards national publications but there is a growing orientation towards 'international' journals.

Third methodological question is how to delineate the IR 'mainstream'. The paper examines whether and how Chinese, Indian and Brazilian scholars can speak in top Anglo-American journals as defined in the most recent TRIP (Teaching, Research and International Policy) survey conducted among IR scholars in 20 countries (excluding China and India, though). ${ }^{14}$ The top 20 journals identified in the survey are, in descending order, International Organization, International Studies Quarterly, International Security, Foreign Affairs, American Political Science Review, World Politics, European Journal of International Relations, Journal of Conflict Resolution, Foreign Policy, Review of International Studies, Millennium: Journal of International Studies, American Journal of Political Science, International Affairs, Security Studies, Review of International Political Economy, Journal of Peace Research, International Studies Review, International Relations, Comparative Politics and Global Governance. There is indeed an Anglo-American and mainstream bias to this particular list, but as I am interested here in studying what enters the AngloAmerican IR mainstream, this should make for a good indicator. I then use the Web of Science database to search for publications authored or co-authored by scholars based in China (mainland), India and Brazil in the period 1990 to 2014 (October 20). ${ }^{15}$

This search results in 120 publications including research articles, book reviews and editorial material (43 Chinese, 22 Brazilian and 55 Indian). There has been a gradual increase in the absolute number of publications in recent years, especially from China. In relative terms, however, publications from authors based in mainland China accounted only for $1.1 \%$ of all articles in these 20 journals in 2013, the best year so far, while India peaked with in $0.6 \%$ of publications 2009 and Brazil with $0.1 \%$ in 1998. In the recent five years, China has published fewer articles in these 20 journals than smaller countries like Norway, Sweden, Switzerland, Wales and Israel, while Brazil and India account for even fewer articles than countries like Finland, Spain, North Ireland and Singapore. Articles are published by relatively few cities and institutions in all three countries - the 'cores in the periphery': Chinese articles are highly concentrated around Beijing (35 articles) and Shanghai (10), the two main centers for IR research in China. Similarly, Sao Paulo (10), Rio de Janeiro (7) and Brasilia (6), the three main Brazilian centers, produce most Brazilian articles (except one coming out of Florianopolis). In India, the major center for IR is New Delhi (28), which looms above the rest, but there are also numerous contributions from institutions in South India (notably Goa and Andhra Pradesh). Moreover, most articles are produced by scholars based at a few elite periphery institutions such as Fudan, Peking and Tsinghua in China, Jawaharlal Nehru University in India and University of São Paulo and Fundação Getulio Vargas in Brazil. Also worth noting is that international coauthorship links are also centered around these periphery hubs. Coauthored articles are usually written with authors based in the United States or Europe. Beijing is particularly integrated with its coauthorship connections to 25 different cities primarily in Europe and North America. In comparison, Delhi and Sao Paulo are linked to 3 cities, Brasilia to 2 and Rio de Janeiro to none. Coauthorship not only indicates integration into global IR, however. The fact that almost half of the Chinese articles (18) are coauthored with scholars from abroad suggests that it is more difficult for scholarship authored only by Chinese scholars to get published in these journals. Language capacities may play a role compared to India and Brazil where the proportion of 
coauthored work is much lower. In sum, measured by relative presence in these top IR journals, 'emerging powers' like China, India and Brazil cannot speak in the mainstream IR discourse. The few articles that do get published are worth examining more close, however.

The following sections turn to the specific ways emerging powers speak in mainstream IR. In terms of content, it looks primarily at whether articles are theoretical/conceptual or empirical/case studies. If theoretical, what kind of theoretical framework do they present and are they positioning their theoretical argument in the mainstream IR discourse (e.g. the great debates, the isms, theories and methodologies) or as, say, 'Chinese School theorizing' or 'Brazilian concepts'? If empirical, is the focus primarily on (international political) economy or security? Do empirical articles study cases from their own national or regional environment and function mainly as providers of local data or do they study any region of the world? Moreover, in terms of local expertise, do authors write as representative of their country's view on a specific policy issue? Do they specifically address the Western literature on their country? (e.g. the 'China threat' and peaceful rise discourse). I outline three ways of speaking that emerging powers can speak in the IR mainstream: theory speak, native informant speak and quasi-official speak. Needless to say, these three ways of speaking are not mutually exclusive and some articles speak in more than one way.

\section{Theory Speak}

The first impression from reading these articles is that purely theoretical articles are quite rare. The presence of theoretical articles depends, of course, on the definition of 'theory'. The aim here is to be as inclusive as possible and 'theory speak' thus includes all articles that frame their contribution as one of making a move in existing or emerging theoretical debates and literatures (this framing will often appear in introductions and conclusions) or articles that set up and apply an analytical framework as opposed to, say, simply start describing recent foreign policy events in their country. I also include critiques or tests of theory and even articles that make methodological contributions.

A Chinese article on game theory and rational choice, specifically "how to cope with noise in the iterated prisoner's dilemma" is an example of a purely theoretical and methodological article. ${ }^{16}$ Similarly, an Indian article presents a mathematical model for interaction in domestic political hostility. ${ }^{17}$ These articles are probably the most universalist and rationalist of all articles examined here. Their mathematical approaches to theorizing bear no traces whatsoever of 'local theorizing' or empirical context for that matter. The same can be said about the theoretical work of Chinese scholar Tang Shiping, which accounts for 7 of the Chinese articles. Tang's articles almost all seek to advance 'theory'-mostly within a realist paradigm (offensive, defensive, neo- and neoclassical) - ranging from a social evolutionary model that incorporates and theorizes both material and ideational variables ${ }^{18}$ and the social evolution from offensive towards defensive realism ${ }^{19}$ through reviews, specifications and retheorizations of the "security dilemma" 20 and its development into a dynamic and integrative theory of ethnic conflict ${ }^{21}$ as well as individual articles on neoclassical realism, ${ }^{22}$ reconciliation, ${ }^{23}$ and reputation. ${ }^{24}$ The theories advanced are not prefixed as 'Chinese theory' or a 'Chinese school', as one might have expected given the Chinese theory debates mentioned above, but simply as 'theory'. The articles build exclusively on American, and sometimes European, IR theorists such as Mearsheimer, Butterfield, Herz and Jervis on the security dilemma. These articles are never about China per se and in several articles the only mention of China is in the author affiliation. Instead, theories are advanced and applied to empirical cases such as "American military interventionism". ${ }^{25}$ One Indian article speaks theory in a similar way. It shows how global norms can be constructed through deliberative processes using in the case of the World Commission of Dams. The empirical case study is not the main contributions, however, instead the article seeks to make a move in the constructivist literature on argumentative rationality, 
norm cycles, epistemic communities and transnational advocacy networks. ${ }^{26}$ These ways of speaking in mainstream IR make universal, or at least non-Chinese/Indian, moves in existing theoretical debates within realism or constructivism. Articles directly advancing the project of local theorizing — as in a 'Chinese School' or 'Brazilian concepts' — are nonexistent.

However, there are other ways to speak theory in mainstream journals that engage more with local culture and history, particularly in articles that engage constructivist strands of IR theorizing (from mainstream constructivism and the English School to postcolonialism). The best example is Partha Chatterjee's short essay "Whose imagined community?" that presents a postcolonial critique of Benedict Anderson's imagined community. ${ }^{27}$ It does so by showing its limits in understanding the history of Indian nationalism and instead presenting a different theorization of nationalism in postcolonial contexts. Another Indian article on "Nuclear Weapons and Indian Strategic Culture" speaks to the existing theoretical literature on strategic culture (largely realist with some constructivist/cultural elements) but does so using empirical insights from India. ${ }^{28}$ The argument is that India's strategic culture mediates between structural pressures of the international system and domestic choices and thus explains its restrained, stable and minimal nuclear policy. In doing so, it rejects essentialist portrayals of Indian strategic culture such as George Tanham's argument that India's cyclical and mythical concept of time prevent any long-term planning in the Western sense (something a lot of Indian IR scholars do). ${ }^{29}$ Another article that frames its contribution as theoretical, but does so using local history and culture as empirical material, is that by Erik Ringmar, a Swede then based in China. The article proposes a performative approach to international systems based on micro-sociological theory and draws empirical lessons in part from the performance and rituals of the Sinocentric tributary system during the Qing Dynasty. ${ }^{30}$ By putting the performance of the Chinese international system into a comparative frame (with Tokugawa Japan and Westphalian Europe), it draws conclusions about the different conceptions of space, scripts, membership and performances in each system. Another Chinese article engages the English School on Chinese history, although it is more a review and critique of the Eurocentrism of the English School (as well as other "Western IR theoretical schools") than an advancement of a new theoretical argument. ${ }^{31}$ The article is nonetheless worth noting because it engages Western theory in the debate over the "'rise' of China" and "peaceful rise", notably China's evolving relationship to the international society as it rises ${ }^{32} .33$

A third variety of 'theory speak' takes the form of theory tests. Here an existing theory, usually developed in the US or Europe, is tested empirically, not on 'local' empirical material but general datasets. Theory is engaged but the contribution is framed as empirical/methodological rather than theoretical as such: articles contribute new data, variables, models, tests or statistical tools that may enrich or challenge existing theories. The few articles that speak to mainstream IR this way follow an almost identical structure that first introduces the problem, reviews existing theory, derives hypotheses from it, builds a statistical model, runs the regression, presents results, discusses them and concludes. These articles speak more to comparative politics/political science than IR literature. This type of 'theory speak' is particularly found among Brazilian articles. One example is Przeworski and Limongi's study of modernization "theories and facts" that tests endogenous and exogenous theories of modernization (the relationship between economic growth and democracy). ${ }^{34}$ Another article tests how democratization and economic openness affects social spending in Latin America. ${ }^{35}$ Although it is empirically focused on Latin America, one of its claims to novelty is that is measures variables more accurately. Finally, a coauthored study of foreign aid writes into the rationalist-constructivist debate and confirms constructivist claims that humanitarian discourse drives humanitarian aid allocation. This, and competing, theories are operationalized into hypotheses that are tested statistically on a dataset in a positivist manner. ${ }^{36}$ If 'theory testers' look more like "social science socialized" than "Third World radicals" constructing alternative local 
theories, ${ }^{37}$ it is probably because all articles are coauthored with Americans and the Brazil-based author in all cases holds an American doctorate.

\section{Native Informant Speak}

Most articles accepted by mainstream journals are empirical articles about China, India and Brazil. Qua their access to local literature and policymakers as well as the concrete experiences of living in those countries, the native informant speaks authoritatively on his/her own country. The role of the native informant "is to provide information, to act as a source and an object of knowledge." ${ }^{38}$ While theory speak rarely provides room for difference, the native informant speaks difference, albeit experiential difference only. These Chinese, Indian and Brazilian intellectuals (elites) become "native informants for first-world intellectuals interested in the voice of the Other." 39 They inform the West/North about what life is like in the East/South. The native informant thus speaks only for the particular, never for the general/theoretical. As Aydinli and Mathews argue in the context of IR, "when the periphery is recognized, it is not to contribute to the larger theoretical discussion, but to add understanding of a particular country or region." posited in a hierarchical relationship to the mainstream discipline and its theorizers. The role of "local informants" is to provide concrete-and different-experiences to the center's generalizations and theorization. ${ }^{41}$ Native informants work as "servants" in the global "House of IR", as Agathangelou and Ling put it, they are domesticated Others providing local data about concrete low politics to the masters who can then theorize about the general aspects of high politics. ${ }^{42}$ There is an asymmetry in the logic native informants, Walter Mignolo argues: "if you 'come' from Latin America you have to 'talk about' Latin America; that in such a case you have to be a token of your culture. Such expectation will not arise if the author is 'comes' from Germany, France, England or the US. In such cases it is not assumed that you have to be talking about your cultural but can function as a theoretically minded person. As we know: the first world has knowledge, the third world has culture."

A variety of 'native informant speak' presents current debates going on within their country/language to foreign audiences. One example is a special issue on IPE with "China's characteristics" where Chinese scholars coauthor articles with North American and European scholars on how IPE has developed in China and survey scholarship on hegemony, global governance, globalization, money and finance and constructivism. ${ }^{44}$ The articles are not framed as theoretical contributions per se, but as contributions with native information on how IPE is done in China (one wonders why all articles need a coauthor based outside China). These articles are exceptional in that they do engage the Chinese debates on IPE/IR 'with Chinese characteristics'. Some even expect "uniquely 'Chinese' approaches to this area of inquiry, approaches informed by China's position in the world and China's rich cultural and intellectual traditions [but find that] it has produced little new knowledge and theoretical innovation". ${ }^{45}$ Other native informants present empirical analyses of China in international relations, the majority of which address the implications of the rise of China. Some directly engage the 'China threat' discourse and seek to elaborate and discuss China's policy of peaceful rise ${ }^{46}$. Others engage the related debate over whether China is becoming socialized and integrated into the US-led liberal world order or seeks to advance an alternative 'China model'. Some examples here are an article on the 'Beijing Consensus' versus 'Washington Consensus' that presents Chinese debates over the 'China model', largely framed by the question of whether a rising China will impose an alternative model. ${ }^{47}$ Another political economy article on the China 'model' vis-à-vis the Washington Consensus that focuses on China's socialization into norms of international institutions (the IMF) is also framed by the question whether China "is seeking to integrate itself into the existing patterns of global 
governance so that it can play the role of responsible stakeholder? Or does it aim at a different world order, where it leads the developing world in redressing the balance of power away from the developed West?"48 An article on Chinese Africa policy "from the perspective of Chinese scholars" also takes its point of departure in the "rising of China" and "Washington Consensus vs. Beijing Consensus" but instead proposes a "win-win" framework for cooperation among China, Africa and Western countries. ${ }^{49}$ A study of how other states accommodate to China's rise in terms of resource politics is, of course, also introduced with the story of how China's remarkable growth, transformation and energy thirst forces others states "to accommodate the 'rise of China' and the threats and opportunities that this overworked expression implies". 50 This article, coauthored by one Chinese, an Australian and South African, also aims to present "a Chinese perspective" on resource politics. Although this is not clear, one easily assumes that the contribution of the Chinese coauthor was to provide 'the Chinese perspective'. Chinese articles are not only about China's (Peaceful) Rise but this is often an implicit element and serves as the general framing in the introduction or conclusion. For example, a native informant speaking about European Studies in China concludes with a discussion about how "European models" and "Europe as an example of peaceful rise" might provide inspiration on how to alleviate worries about the "China threat" among China's neighbors, how to achieve regional integration and learn to coexist peacefully with the US. ${ }^{51}$ Most articles thus speak into the 'China threat' versus 'Peaceful Rise' or 'revisionist' versus 'status quo' discourse. ${ }^{52}$

Brazilian native informants exhibit a similar focus on the country's emergence as a middle or great power and its membership in BRICS, IBSA and other emerging power groupings, especially after the mid-2000s. When Brazilian authors spoke as 'native informants' in mainstream journals before the 2000s, the focus was on Brazil's economy, development and international political economy. For example, a descriptive study of the Brazilian economy before and after the fiscal crisis ${ }^{53}$ or a study of civil society responses to the implementation of international development bank programs to stabilize the Brazilian economy. ${ }^{54}$ The contributions here are framed as empirical ("the case of Brazil") about how Brazil or the "South" respond to such programs from the center. ${ }^{55}$ Other early IPE studies focus not only on Brazil but trace the general development from protectionist import substitution models towards trade liberalization in the 1980s and 1990s in the Americas ${ }^{56}$ or in the World Bank. ${ }^{57}$ Later articles start analyzing Brazil through the 'emerging power' prism. Some are part of BRICS forums or special issues that set the stage for an empirical contribution: this is the article on the 'B in BRICS'. Here Brazil-based scholars contribute empirical and historical information on their own country in order to explain its foreign policy decisions and bilateral relationships. ${ }^{58}$ Another article presents an account of the formation of the BRICS grouping in the wake of post-financial crisis delegitimization of global governance (with most empirical examples from Brazil). ${ }^{59}$ There is an element of trying to explaining to a Western audience why Brazil and BRICS aspire for recognition and to argue that Brazil is a positive force for change in a conservative order, a mediator between the weak and the strong that deserves more influence because it is a peaceful country that has settled all its territorial disputes and does not "value military deterrence as a source of international and/or regional prestige." $" 60$ These articles border the quasi-official speak outlined below. Except from the empirical material drawn from Brazil it is difficult to ascertain whether these articles have 'Brazilian characteristics'. There is no engagement with a 'Brazil threat' theory parallel to that of Chinese articles, partly because there is no 'Brazil threat' theory but also because the focus is more on political economy than security. Consequently, Brazilian articles tend to invoke a North-South rather than an East-West geographical imaginary: as in South-South cooperation like IBSA and BRICS or the hegemony of North over South. This geographical imaginary is not only a product of Brazil's geographical location in the Western and Southern hemisphere, but also because the IPE focus draws attention to dependency-inspired questions of how Southern underdevelopment is related to Northern 
development. Another Brazilian characteristic is arguably the policy-oriented histories of Brazilian (or BRICS) foreign policy that move chronologically and descriptively through policy events. ${ }^{61}$

Indian native informants also tend to gain access to mainstream IR not only because they provide useful local information for the center's theorization but also because they speak to Western security concerns. One way of doing so is to survey how India is doing in global rise and fall of great powers. An article on "India in the twenty-first century" describes a country growing economically, and in self-confidence, and goes through achievements and challenges in domestic politics, economy and foreign policy. ${ }^{62}$ Fifteen years later, an article called "How India Stumbled" informs Foreign Affairs readers on domestic explanations why "shining" India was supplanted by stagnating economic growth, growing social inequality and political deadlock. ${ }^{63}$ There is no India threat theory, but several studies nonetheless contain an element of reassurance stressing that India is not only destined to emerge as a major economic and military power on par with China, but as a major democratic country: "the world's largest democracy" that will emerge "flying its economics flag and not parading its military might and making proclamations of power." 64 Elsewhere, India is represented as a restrained "status quo" power despite provocations from "irredentist Pakistan" and its ally China. ${ }^{65}$ Other articles speak to more specific security concerns. For instance, a study of Indian strategic culture that explains India's nuclear policy to the West a few of years after India officially went nuclear, much to the chagrin of the US. ${ }^{66}$ Some years later, the American/Western security agenda shifted towards terrorism and an article on "Terrorism in South Asia" published shortly after 9/11 explains how India as a "leading victim" of international terrorism "shares common interests with the West in the counterterror campaign" and therefore supports the American war on terror. ${ }^{67}$ The article not only speaks about South Asia but does so, in typical International Security format, with policy recommendations for the United States: The United States should "behave as the leader of the world" and the democratic "values the West stands for" but also realize that "the only defense against the sly, murderous terrorists is offense aimed at hounding, disrupting, and smashing their calls, network, and safe havens." ${ }^{\circ 8}$ India is probably the emerging power with most empirical contributions that do not follow the logic of native informants. There are a number of Indian articles on climate change and environmental governance, ${ }^{69}$ one on ASEAN and the financial crisis ${ }^{70}$ and the effect of "celebrity diplomacy" on development. ${ }^{71}$ Some of these articles contain elements of seeing the world from a developing country or Global South perspective, ${ }^{72}$ but are not only 'native informants' reporting on their own country.

\section{Quasi-Official Speak}

A third way of speaking in Western IR discourse is quasi-official speak. This is related to the native informant but the difference is that quasi-officials not only contribute with 'local data', they also aim to represent their country's view on the world. While native informants are accepted by mainstream journals because they provide empirical material of a certain truth-value about their country/region, the quasi-official is accepted because he (it is only men) speaks for the country and its leadership. In the case of emerging powers, quasi-official speak becomes interesting to mainstream IR because it tells the 'West' something about 'how the Chinese view the world'. It is epiphenomenal and politicized discourse. Quasi-official speak is accepted largely because of the position from which it is spoken, not only what is spoken. It tends to come from scholars who are also advisors, diplomats, government officials or work in international organizations or NGOs. ${ }^{73}$

Quasi-official speak is exemplified by Wang Jisi's Foreign Affairs articles that not only try to represent the Chinese perspective ("Here is a Chinese view"), but also does so in the typical Realpolitik discourse of Foreign Affairs where states (usually referred to as capitals, Beijing and Washington) are the primary units trying to safeguard their "core interests" against external 
"threats" "74: "Washington will not regard Beijing as its main security threat" and "many Chinese still view the United States as a major threat". ${ }^{75}$ While quasi-official speak tries to explain China's foreign policy concepts and leadership intentions to the world, i.e. the US, it does so within the Western frame of "China's rise" and "China threat' theory" ${ }^{76}$ As Wang argues in relation to debates about a China model, the Beijing Consensus and China Dream, "the Chinese leadership does not dream of turning China into a hegemon or a standard-bearer", rather "it is in China's interest to contribute to a peaceful international environment." 77 Foreign Affairs also published an interview with the Chinese ambassador to the US explicating Xi Jinping's notion of a "new type of great-power relationship" based on "mutual respect and mutual benefit" rather than a "zero-sum game" and explaining why China is not "revisionist" power but seeks integration and follows the rules: "We stand for necessary reform of the international system, but we have no intention of overthrowing it or setting up an entirely new one." and "We never provoked anything. We are still on the path of peaceful development". ${ }^{78}$ Quasi-official articles represent 'the Chinese view' in reassuring plus-sum terms that posit China as peaceful and only "rightfully" aiming for international restoration and responsibility. ${ }^{79}$

Similarly, an Indian article in Foreign Affairs tries to correct America's "negative view" of India (its nuclear aspirations) as a "revisionist state destined to be at odds with the United States". 80 It criticizes the "West" for having unstated assumptions that "leaders of developing countries are more irresponsible, volatile and cavalier with the lives of their people." The argument is that America's "faulty assumptions" leads to a "misreading" of India ("why don't you understand us') and the article sets out to clarify "India's view" and "the Indian perspective" on things. There is a tone of humiliated civilizational pride where India "as an ancient civilization subjected to prolonged British colonial rule" would obviously defend its independence with all possible means, nuclear included, but does not have the offensive ambitions of an "aspiring hegemon". ${ }^{81}$ The article on terrorism mentioned above also contains quasi-official elements when it explains what "India's main concern is" with the US-Pakistan relationship and how "India was disappointed" that the US did not target Pakistan in the war on terror. ${ }^{82}$

A Brazilian scholar-diplomat also attempts to explain Brazil's diplomacy and international identity authoritatively using terms such as "in Brazil's view of the world", the "Brazilian attitude" and "how Brazil sees it". ${ }^{83}$ It represents an quasi-official view by characterizing Brazilian foreign policy as essentially peaceful, tolerant of differences, a diplomatic bridge-builder, multilaterally engaged, by defending why Brazil's candidacy for a permanent seat in the Security Council is "natural" and its "credentials are indisputable" or by arguing that developed countries are the illiberal ones in terms of trade while Brazil is a "fair partner" with "legitimate interests to protect". ${ }^{84}$ Likewise, the contribution is that of a "Brazilian" perspective based on "experience" when a discussion of the World Bank's "identity crisis" by a former Brazilian finance minister starts with the sentence: "in this article, the author, the Brazilian Finance Minister in the late 1980s uses his insights and experience to examine critically the identity crisis of the World Bank." 85 Although he mentions development theory, dependency theory, imperialist theories of underdevelopment and neoliberalism, the contribution is inevitably framed as a Brazilian view on the World Bank's neoliberal reforms, not a theoretical or even scholarly contribution.

\section{Conclusion: How Can Emerging Powers Speak?}

In quantitative terms, emerging powers still cannot speak in mainstream IR. Like scholars in other non-core, non-Western, non-Northern settings, the majority of Chinese, Indian and Brazilian are 'subaltern' in the sense of having no voice in mainstream IR. It is difficult to ascertain whether the problem is that 'they' are not talking or 'we' are not listening. ${ }^{86}$ This paper has shown that when 
'we' are listening, however, the few articles that access the infrastructure of global/Western IR discourse tend to speak in one of three voices: first, as theorizers within established Western theoretical traditions such as realism, constructivism or English School. Second, as native informants presenting empirical material from their own country. Third, as quasi-officials representing a perspective from their country. Theory speak from 'non-Western' IR scholars does not deliver the radical difference usually expected from scholars based in a different context - there are no "third world radicals" or indigenous theorizers in mainstream journals - rather it often looks like "social science socialized" disciplined by a mainstream discipline. ${ }^{87}$ The majority, however, speak about or for their own country and region. In the past decade, they do so increasingly using the 'emerging power' prism. There is no doubt that the growing attention to emerging powers opens up the discursive space of IR for scholars located in these emerging powers to speak at all. However, native informants and quasi-officials not only speak about and for themselves, they often do so within a securitized discourse. Particularly Chinese articles frame their empirical contributions by the debate over the 'China threat' and 'peaceful rise'. It seems that Chinese scholars must, at least peripherally, engage the 'China threat' discourse to get published in a mainstream Anglo-American journal. But why would even articles on political economy be dressed up in security speak? Why does a Chinese scholar frame the study of, say, China in the IMF in terms of whether China is a threat or not, whether it will be peaceful or not? It is almost inconceivable that articles on Germany or the United States in the IMF would have a similar framing. It is somewhat paradoxical to read Chinese scholars debating whether their own country will be revisionist or status quo oriented, whether it will overturn the American-led liberal order or integrate into it-questions infused by American/Western security concerns and a status quo bias. This mode of 'speaking back' has its pitfalls because it is always more of a negation to American threat theories, a 'non-China threat theory', than an opening for alternative and innovative theorizing. Although there is no India threat theory, Indian scholars are not exempt from this logic when they try to correct negative American images of India and reassure that India will be a different, democratic great power nor are Brazilians who try to explain why Brazil and the BRICS seeks greater influence. This raises the question whether 'non-Western' emerging powers can speak in IR without always already speaking back to the 'West', its theories and security agendas?

\section{Notes}

\footnotetext{
${ }^{1}$ Previous versions of this paper were presented at workshops and conferences in China, Japan and the United States. I would like to thank participants Ching-Chang Chen, Tim Dunne, Xavier Guillaume, Josuke Ikeda, Kohei Imai, Hun Joon Kim, Ren Xiao, Shiro Sato, Hiroyuki Suzuki, Arlene Tickner, Kazuhiro Tsunoda, Wiebke Wemheuer-Vogelaar, Ole Wæver, Xu Tao, Zhang Feng, Zhang Yongjin for their valuable comments and criticisms. I would like to thank the JAIR young scholars team, the EU institute at the University of Kyushu, Griffith University Asia Institute and the Asian Dynamics Initiative for providing funding for the participation in those events. The usual disclaimer applies.

${ }^{2}$ Qin, "Why is there no Chinese international relations theory?"; Ren, "Toward a Chinese school"; Kristensen and Nielsen, "Constructing a Chinese International Relations Theory".

3 Alagappa, "Strengthening International Studies"; Shahi, "Indian Scholarship”; Mattoo, “An Indian grammar".

${ }^{4}$ Cervo, "Conceitos em Relações Internacionais"; Saraiva, Concepts, Histories and Theories of International Relations.

5 Aydinli and Mathews, “Are the Core and Periphery Irreconcilable?"; Holsti, The Dividing Discipline; Tickner, "Core, periphery and (neo)imperialist International Relations".

${ }^{6}$ Kristensen, "Revisiting the "American Social Science"”.

${ }^{7}$ Kristensen, "International Relations in China and Europe".

${ }^{8}$ Ibid.

${ }^{9}$ Lessa, "Instituições, atores e dinâmicas", 9; Fonseca, "Studies on International Relations in Brazil”, 273.

${ }^{10}$ Bajpai, "Obstacles to Good Work", 122; Basrur, "Scholarship on India's International Relations", $103-105$.

${ }^{11}$ Bajpai, "International Studies in India", 32.
} 
${ }^{12}$ Alagappa, "Strengthening International Studies in India", 11; Basrur, "Scholarship on India's International

Relation:"; Sharma, "Mapping International Relations", 69.

${ }^{13}$ Basrur, "Scholarship on India's International Relations", 90.

${ }^{14}$ Maliniak, Peterson, and Tierney, TRIP Around the World.

${ }^{15}$ Authors without registered affiliation in Web of Science are excluded. Also excluded are scholars only partially based as honorary or visiting professors or affiliated with subsidiaries of foreign institutions. I exclude non-IR articles from general political science journals (e.g. articles on the Brazilian legislature, judiciary, central bank, the presidency, parties, voting behavior and a few from China on advancement in the Communist Party and collective petitioning in rural China).

${ }^{16} \mathrm{Wu}$ and Axelrod, "How to Cope with Noise".

${ }^{17}$ Karmeshu, Jain, and Mahajan, "A Dynamic-Model".

${ }^{18}$ Tang and Long, "America's Military Interventionism".

${ }^{19}$ Tang, "Social Evolution of International Politics".

${ }^{20}$ Tang, "The Security Dilemma".

${ }^{21}$ Tang, "The Security Dilemma and Ethnic Conflict".

${ }^{22}$ Tang, "Taking Stock of Neoclassical Realism".

${ }^{23}$ Tang, "Reconciliation and the Remaking of Anarchy".

${ }^{24}$ Tang, "Reputation".

${ }^{25}$ Tang and Long, "America's Military Interventionism".

${ }^{26}$ Dubash, "Global Norms Through Global Deliberation?".

${ }^{27}$ Chatterjee, "Whose Imagined Community".

${ }^{28}$ Basrur, "Nuclear Weapons and Indian Strategic Culture".

${ }^{29}$ Ibid., 183.

${ }^{30}$ Ringmar, "Performing International Systems".

${ }^{31}$ Zhang, "China in the Conception of International Society".

${ }^{32}$ Ibid., 785, 777-779.

${ }^{33}$ Other Chinese articles also discuss English School conceptions of "balance of power", Zhang, "Reconceiving the Balance of Power". Or "world society" exemplified in the case of trans-Atlantic slave trade, Pella, "Thinking Outside International Society". While these are discussions of the English School, not the advancement of a distinctly "Chinese school', there are certain linkages and overlaps between the two, Wang and Buzan, "The English and Chinese Schools".

${ }^{34}$ Przeworski and Limongi, "Modernization - Theories and Facts".

${ }^{35}$ Avelino, Brown, and Hunter, "The Effects of Capital Mobility".

${ }^{36}$ Buethe, Major, and Souza, "The Politics of Private Foreign Aid".

${ }^{37}$ Bilgin, "Thinking past 'Western' IR?".

${ }^{38}$ Sanders, "Postcolonial Reading", 3.

${ }^{39}$ Spivak, "Can the Subaltern Speak?", 38.

${ }^{40}$ Aydinli and Mathews, "Are the Core and Periphery Irreconcilable?", 297.

${ }^{41}$ Tickner and Wæver, International Relations Scholarship, 8; Chen, "The absence of non-western IR", 18.

${ }^{42}$ Agathangelou and Ling, "The House of IR", 31.

${ }^{43}$ Mignolo, "Epistemic disobedience", 2.

${ }^{44}$ Chin, Pearson, and Yong, "Introduction - IPE with China's Characteristics". Yong and Pauly, "Chinese IPE Debates on (American) Hegemony".

${ }^{45}$ Zhongying and Wang, "Debating International Institutions".

${ }^{46}$ Zha, "Comment".

${ }^{47}$ Ferchen, "Whose China Model".

${ }^{48}$ Ferdinand and Wang, "China and the IMF", 895.

${ }^{49}$ Luo and Zhang, "Multilateral Cooperation in Africa", 1794-1795, 1804.

${ }^{50}$ Beeson, Soko, and Wang, "The New Resource Politics", 1365.

${ }^{51}$ Song, "European 'Models"”.

${ }^{52}$ One article focusing on political economy - China's economic rise and the relationship to political decentralizationis not framed explicitly by the China threat discourse but nonetheless concerned with China's rise in a broader sense, Cai and Treisman, "Did Government Decentralization Cause China's Economic Miracle?".

${ }^{53}$ Rezende, "The Brazilian Economy".

${ }_{55}^{54}$ Vianna, "Civil Society Participation".

${ }^{55}$ Ibid., 468.

${ }^{56}$ Wrobel, "A Free Trade Area".

${ }^{57}$ Bresser Pereira, "Development Economics". 


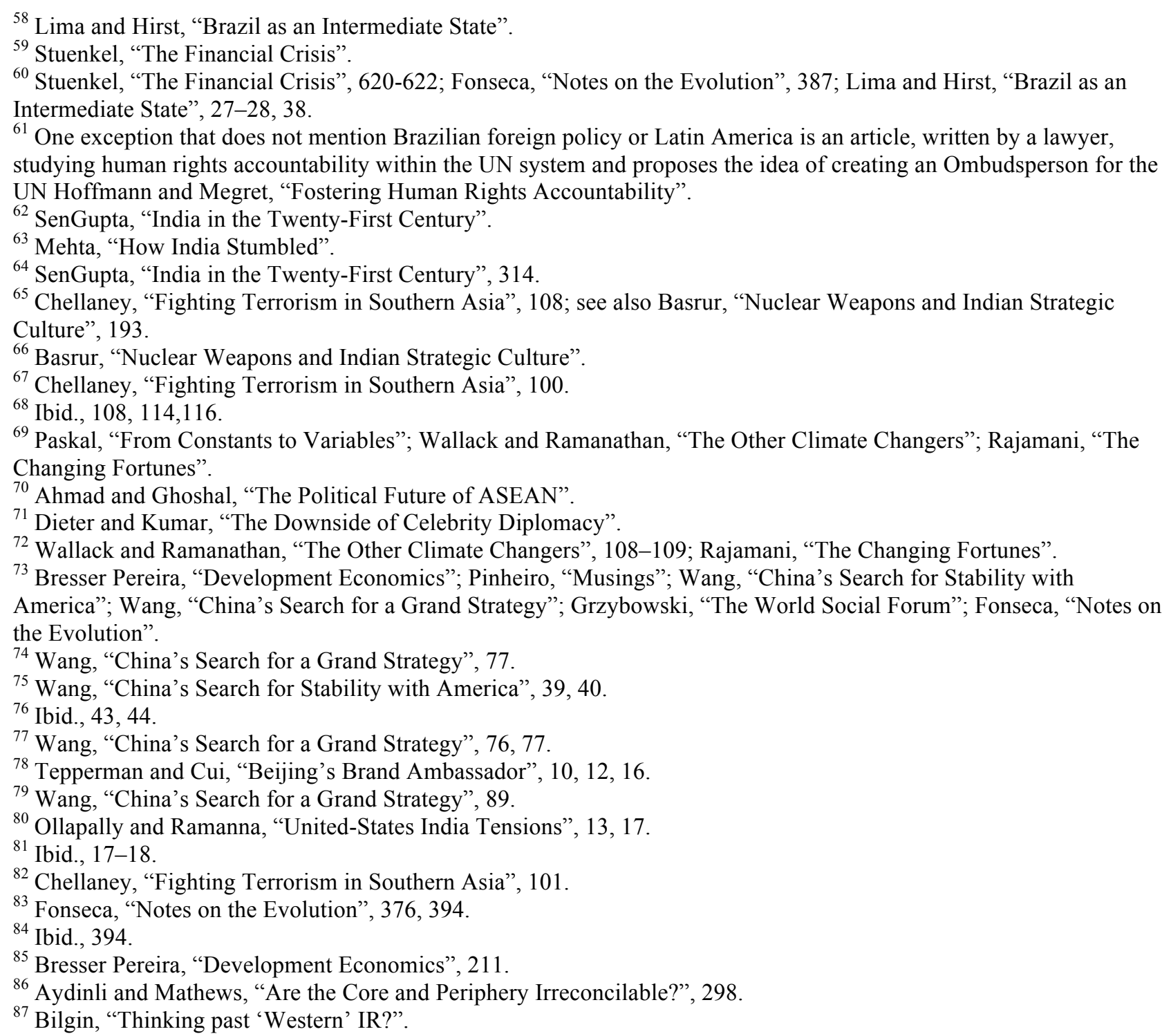

\section{Bibliography}

Agathangelou, Anna, and L.H.M. Ling. “The House of IR: From Family Power Politics to the Poisies of Worldism”. International Studies Review 6, no. 4 (2004): 21-49.

Ahmad, Zakaria, and Baladas Ghoshal. "The Political Future of ASEAN after the Asian Crisis". International Affairs 75, no. 4 (1999): 759-78.

Alagappa, Muthiah. "Strengthening International Studies in India: Vision and Recommendations". International Studies 46, no. 1-2 (2009): 7-35.

Avelino, George, David Brown, and Wendy Hunter. "The Effects of Capital Mobility, Trade Openness, and Democracy on Social Spending in Latin America, 1980-1999”. American Journal of Political Science 49, no. 3 (2005): 625-41.

Aydinli, Ersel, and Julie Mathews. "Are the Core and Periphery Irreconcilable? The Curious World of Publishing in Contemporary International Relations”. International Studies Perspectives 1, no. 3 (2000): 289-303.

Bajpai, Kanti. "International Studies in India: Bringing Theory (Back) Home". In International and Area Studies in India, edited by M.S. Rajan. New Delhi: Lancers, 1997.

"Obstacles to Good Work in Indian International Relations". International Studies 46, no. 1-2 (2009): 109-28.

Basrur, Rajesh. "Nuclear Weapons and Indian Strategic Culture". Journal of Peace Research 38, no. 2 (2001): 181-98. 
. "Scholarship on India's International Relations: Some Disciplinary Shortcomings". International Studies 46, no. 1-2 (2009): 89-108.

Beeson, Mark, Mills Soko, and Yong Wang. "The New Resource Politics: Can Australia and South Africa Accommodate China?". International Affairs 87, no. 6 (2011): 1365-84.

Bilgin, Pinar. “Thinking past 'Western' IR?”. Third World Quarterly 29, no. 1 (2008): 5-23.

Bresser Pereira, Luiz Carlos. "Development Economics and the World Bank's Identity Crisis". Review of International Political Economy 2, no. 2 (1995): 211-47.

Buethe, Tim, Solomon Major, and Andre de Mello e Souza. "The Politics of Private Foreign Aid: Humanitarian Principles, Economic Development Objectives, and Organizational Interests in NGO Private Aid Allocation". International Organization 66, no. 4 (2012): 571-607.

Cai, Hongbin, and Daniel Treisman. “Did Government Decentralization Cause China’s Economic Miracle?”. World Politics 58, no. 4 (2006): 505-535.

Cervo, Amado Luiz. "Conceitos em Relações Internacionais". Revista Brasileira de Politica Internacional 51, no. 2 (2008): 8-25.

Chatterjee, Partha. "Whose Imagined Community". Millennium 20, no. 3 (1991): 521-25.

Chellaney, Brahma. "Fighting Terrorism in Southern Asia - The Lessons of History". International Security 26, no. 3 (2001): 94-116.

Chen, Ching-Chang. "The absence of non-western IR theory in Asia reconsidered". International Relations of the AsiaPacific 11, no. 1 (2011): 1-23..

Chin, Gregory, Margaret Pearson, and Wang Yong. "Introduction - IPE with China's Characteristics". Review of International Political Economy 20, no. 6 (2013): 1145-64.

Dieter, Heribert, and Rajiv Kumar. "The Downside of Celebrity Diplomacy: The Neglected Complexity of Development”. Global Governance 14, no. 3 (2008): 259-64.

Dubash, Navroz. "Global Norms Through Global Deliberation? Reflections on the World Commission on Dams". Global Governance 15, no. 2 (2009): 219-38.

Ferchen, Matt. "Whose China Model Is It Anyway? The Contentious Search for Consensus". Review of International Political Economy 20, no. 2 (2013): 390-420.

Ferdinand, Peter and Wang Jue. "China and the IMF: From Mimicry towards Pragmatic International Institutional Pluralism”. International Affairs 89, no. 4 (2013): 895-910.

Fonseca, Gelson. "Notes on the Evolution of Brazilian Multilateral Diplomacy". Global Governance 17, no. 3 (2011): 375-97.

"Studies on International Relations in Brazil: Recent Times (1950-80)". Millennium 16, no. 2 (1987): $273-80$.

Grzybowski, Candido. "The World Social Forum: Reinventing Global Politics”. Global Governance 12, no. 1 (2006): $7-13$.

Hoffmann, Florian, and Frédéric Megret. "Fostering Human Rights Accountability: An Ombudsperson for the United Nations?". Global Governance 11, no. 1 (2005): 43-63.

Holsti, Kalevi. The dividing discipline: hegemony and diversity in international theory. Boston: Allen \& Unwin, 1985.

Karmeshu, VP Jain, and AK Mahajan. "A Dynamic-Model of Domestic Political-Conflict Process". Journal of Conflict Resolution 34, no. 2 (1990): 252-69.

Kristensen, Peter Marcus. "International Relations in China and Europe: the Case for Interregional Dialogue in a Hegemonic Discipline". Pacific Review, 2014.

"Revisiting the 'American Social Science' - Mapping the Geography of International Relations". International Studies Perspectives, 2014.

Kristensen, Peter Marcus, and Ras Tind Nielsen. "Constructing a Chinese International Relations Theory: A Sociological Approach to Intellectual Innovation”. International Political Sociology 7, no. 1 (2013): 19-40.

Lessa, Antônio Carlos. "Instituições, atores e dinâmicas do ensino e da pesquisa em Relações Internacionais no Brasil: o diálogo entre a história, a ciência política e os novos paradigmas de interpretação (dos anos 90 aos nossos dias)". Revista Brasileira de Política Internacional 48, no. 2 (2005): 169-84.

Lima, Maria Regina Soares de, and Mônica Hirst. "Brazil as an Intermediate State and Regional Power". International Affairs 82, no. 1 (2006): 21-40.

Luo, Jianbo, and Zhang Xiaomin. "Multilateral Cooperation in Africa between China and Western Countries: From Differences to Consensus". Review of International Studies 37, no. 4 (2011): 1793-1813.

Maliniak, Daniel, Susan Peterson, and Michael Tierney. TRIP Around the World: Teaching, Research, and Policy Views of International Relations Faculty in 20 Countries. College of William and Mary, Williamsburg, Virginia, 2012.

Mattoo, Amitabh. “An Indian grammar for International Studies”. The Hindu, December 11, 2012. http://www.thehindu.com/opinion/op-ed/an-indian-grammar-for-international-studies/article4185358.ece 
Mehta, Pratap. "How India Stumbled Can New Delhi Get Its Groove Back?”. Foreign Affairs 91, no. 4 (2012): 64-75.

Mignolo, Walter. "Epistemic disobedience, independent thought and decolonial freedom". Theory, Culture \& Society 26, no. 7-8 (2009): 159-81.

Ollapally, Deepa, and Raja Ramanna. "United-States India Tensions - Misperceptions on Nuclear Proliferation”. Foreign Affairs 74, no. 1 (1995): 13-18.

Paskal, Cleo. "From Constants to Variables: How Environmental Change Alters the Geopolitical and Geo-Economic Equation". International Affairs 85, no. 6 (2009): 1143-1156.

Pella, John. "Thinking Outside International Society: A Discussion of the Possibilities for English School Conceptions of World Society". Millennium 42, no. 1 (2013): 65-77.

Pinheiro, Paulo. "Musings of a UN Special Rapporteur on Human Rights". Global Governance 9, no. 1 (2003): 7-13.

Przeworski, Adam, and Fernando Limongi. "Modernization - Theories and Facts". World Politics 49, no. 2 (1997): $155-183$.

Qin, Yaqing. "Why is there no Chinese international relations theory?". International Relations of the Asia-Pacific 7, no. 3 (2007): 313-40.

Rajamani, Lavanya. "The Changing Fortunes of Differential Treatment in the Evolution of International Environmental Law". International Affairs 88, no. 3 (2012): 605-623.

Ren, Xiao. "Toward a Chinese school of International Relations". In China and the new international order, edited by Gungwu Wang and Yongnian Zheng, 293-309. London and New York: Routledge, 2008.

Rezende, Fernando. "The Brazilian Economy: Recent Developments and Future Prospects". International Affairs 74, no. 3 (1998): 563-575.

Ringmar, Erik. "Performing International Systems: Two East-Asian Alternatives to the Westphalian Order". International Organization 66, no. 1 (2012): 1-25.

Sanders, Mark. "Postcolonial Reading". Postmodern Culture 10, no. 1 (1999).

Saraiva, José Flávio Sombra (ed.) Concepts, Histories and Theories of International Relations for the 21th Century: Regional and National Approaches. Brasilia: IBRI, 2009.

SenGupta, Bhabani. "India in the Twenty-First Century". International Affairs 73, no. 2 (1997): $297-314$.

Shahi, Deepshikha. "Indian Scholarship on International Relations and Multilateralism". Economic and Political Weekly 48, no. 5 (2013): 50-58.

Sharma, Devika. "Mapping International Relations Teaching and Research in Indian Universities". International Studies 46, no. 1-2 (2009): 69-88.

Song, Xinning. "European 'Models' and Their Implications to China: Internal and External Perspectives". Review of International Studies 36, no. 3 (2010): 755-75.

Spivak, Gayatri. “Can the Subaltern Speak?”. In Can the Subaltern Speak?: Reflections on the History of an Idea, edited by Rosalind Morris. Columbia University Press, 2010.

Stuenkel, Oliver. "The Financial Crisis, Contested Legitimacy, and the Genesis of Intra-BRICS Cooperation". Global Governance 19, no. 4 (2013): 611-30.

Tang, Shiping. "Reconciliation and the Remaking of Anarchy". World Politics 63, no. 4 (2011): 711-49.

. "Reputation, Cult of Reputation, and International Conflict". Security Studies 14, no. 1 (2005): 31-58.

"Social Evolution of International Politics: From Mearsheimer to Jervis". European Journal of International Relations 16, no. 1 (2010): 31-55.

“Taking Stock of Neoclassical Realism”. International Studies Review 11, no. 4 (2009): 799-803.

"The Security Dilemma: A Conceptual Analysis". Security Studies 18, no. 3 (2009): 587-623.

. "The Security Dilemma and Ethnic Conflict: Toward a Dynamic and Integrative Theory of Ethnic Conflict". Review of International Studies 37, no. 2 (2011): 511-36.

Tang, Shiping, and Joey Long. "America's Military Interventionism: A Social Evolutionary Interpretation”. European Journal of International Relations 18, no. 3 (2012): 509-38.

Tepperman, Jonathan, and Tiankai Cui. "Beijing’s Brand Ambassador: A Conversation With Cui Tiankai". Foreign Affairs 92, no. 4 (2013): 10-17.

Tickner, Arlene. "Core, periphery and (neo) imperialist International Relations". European Journal of International Relations 19, no. 3 (2013): 627-46.

Tickner, Arlene, and Ole Wæver. International Relations Scholarship Around the World. London: Routledge, 2009.

Vianna, Andre. "Civil Society Participation in World Bank and Inter-American Development Bank Programs: The Case of Brazil”. Global Governance 6, no. 4 (2000): 457-72.

Wallack, Jessica Seddon, and Veerabhadran Ramanathan. "The Other Climate Changers: Why Black Carbon and Ozone Also Matter". Foreign Affairs 88, no. 5 (2009): 105-13.

Wang, Jiangli, and Barry Buzan. "The English and Chinese Schools of International Relations: Comparisons and Lessons”. Chinese Journal of International Politics 7, no. 1 (2014): 1-46. 
Wang, Jisi. “China’s Search for a Grand Strategy A Rising Great Power Finds Its Way”. Foreign Affairs 90, no. 2 (2011): 68-79.

"China's Search for Stability with America". Foreign Affairs 84, no. 5 (2005): 39-48.

Wrobel, Paulo. “A Free Trade Area of the Americas in 2005?”. International Affairs 74, no. 3 (1998): $547-561$.

Wu, Jianzhong, and Robert Axelrod. "How to Cope with Noise in the Iterated Prisoners-Dilemma". Journal of Conflict Resolution 39, no. 1 (1995): 183-89.

Yong, Wang, and Louis Pauly. "Chinese IPE Debates on (American) Hegemony”. Review of International Political Economy 20, no. 6 (2013): 1165-88.

Zha, Daojiong. “Comment: Can China Rise?”. Review of International Studies 31, no. 4 (2005): 775-85.

Zhang, Feng. "Reconceiving the Balance of Power: A Review Essay". Review of International Studies 37, no. 2

Zhang, Xiaoming. "China in the Conception of International Society: The English School's Engagements with China". Review of International Studies 37, no. 2 (2011): 763-86.

Zhongying, Pang, and Hongying Wang. "Debating International Institutions and Global Governance: The Missing Chinese IPE Contribution”. Review of International Political Economy 20, no. 6 (2013): 1189-1214. 